DOI: $10.29405 /$ bioeduscience/11-18111107

\title{
Pengunaan Metode Giving Questions and Getting Answer terhadap Keaktifan Belajar Siswa SMA
}

\author{
Lissa $^{1^{*}}$ \\ ${ }^{1}$ Pendidikan Biologi, Universitas Wiralodra Indramayu 45213, Indonesia \\ *Email: : Kheshin lissa86yahoo.com
}

\section{ABSTRAK}

Metode pembelajaran di lapangan masih belum variatif dan inovatif serta guru kurang memacu keterlibatan siswa, sehingga berpengaruh terhadap keaktifan belajar siswa. Metode yang dapat melibatkan aktifitas siwa dan membuat siswa aktif yaitu metode Giving Question and Getting Answer. Penelitian ini bertujuan untuk mengetahui pengaruh metode Giving Question and Getting Answer terhadap keaktifan belajar siswa pada materi ekosistem. Jenis penelitian kuantitatif dengan desain penelitian True-Experimental Desigen. Populasi dalam penelitian ini adalah seluruh siswa kelas X MIPA di SMA Negeri 1 Krangkeng tahun akademik 2016/2017 yang berjumlah 166 siswa dengan sampel 2 kelas yaitu kelas X MIPA 1 (eksperimen) yang berjumlah 30 siswa dan kelas X MIPA 2 (kontrol) yang berjumlah 29 siswa yang diperoleh dengan teknik cluster random sampling. Instrumen penelitian yang digunakan adalah lembar observasi keaktifan belajar siswa. Dari hasil analisis data yang telah dilakukan, diperoleh rata-rata skor keaktifan belajar siswa kelas eksperimen menggunakan metode Giving Question and Getting Answer adalah 31,97 dan rata-rata skor keaktifan belajar siswa kelas kontrol menggunakan metode konvensional adalah 29,40. Uji hipotesis yang digunakan yaitu uji $\mathrm{t}$ dan diperoleh nilai $\mathrm{t}_{\text {hitung }}=4,486$ dan $\mathrm{t}_{\text {tabel }}=1,672$. Karena $\mathrm{t}_{\text {hitung }}>\mathrm{t}_{\text {tabel, }}$ maka $\mathrm{H}_{\mathrm{O}}$ ditolak. Artinya penggunaan metode Giving Question and Getting Answer berpengaruh terhadap keaktifan belajar siswa.

Kata kunci: Ekosistem; Keaktifan Belajar Siswa; Metode Giving Question and Getting Answer

Copyright $(2017$ BIOEDUSCIENCE All rights reserved

\section{PENDAHULUAN}

Kementrian Pendidikan dan Kebudayaan mendefinisikan pembelajaran kurikulum 2013 terdiri atas pembelajaran intrakurikuler dan ekstrakurikuler. Pembelajaran intrakurikuler didasarkan pada prinsip-prinsip, diantaranya prinsip pembelajaran siswa aktif untuk menguasai kompetensi dasar dan kompetensi inti pada tingkat yang memuaskan. Prinsip pembelajaran siswa aktif melalui kegiatan mengamati (melihat, membaca, mendengar, menyimak), menanya (lisan, tulis), menganalisis (menghubungkan, menentukan keterkaitan, membangun cerita atau konsep), mengkomunikasikan (lisan, tulisan, gambar, grafik, tabel dan lain-lain). Hal tersebut sejalan dengan Sardiman (2016) Keaktifan adalah kegiatan yang bersifat fisik maupun mental yang berbuat dan berpikir sebagai suatu rangkaian yang tidak dapat dipisahkan.

Fakta lapangan dari berbagai sumber penelitian mengungkapkan bahwa keaktifan belajar siswa pada proses pembalajaran masih rendah yang disebabkan oleh kurangnya interaksi siswa baik dengan guru atau dengan sesama siswa selama proses pembelajaran. Selain itu, penggunaan metode pembelajaran yang monoton dan tidak banyak melibatkan siswa dalam menggunakan alat inderanya dapat menjadikan siswa lebih pasif dan tidak kondusif belajar (Uno dan Mohamad, 2012). Siswa dapat dikatakan aktif belajar apabila memenuhi beberapa indikator berikut: Menurut Paul B. Dierdich yang dikutip oleh Sardiman (2016): (1) Visual Activitles, (2) Oral Activitles, (3) Listening Activitles, (4) Writing Activitles, (5) Drawing 
Activitles, (6) Motor Activitles, (7) Mental Activitles dan (8) Emosional Activitles.

Prinsip pembelajaran yang mengaktifkan siswa diantaranya, yaitu: a). Mendesain pembelajaran yang dapat membuat siswa aktif sepenuhnya dalam proses belajar. Keaktifan fisik, mental dan emosional dapat diupayakan dengan melibatkan sebanyak mungkin indra siswa, semakin banyak keterlibatkan indra itu dalam proses belajar, semakin maksimal keaktifan siswa. b). Membebaskan siswa dari ketergantungan yang berlebihan pada guru. Cara belajar DDCH (Duduk, Dengar, Catat, Hafal) mengakibatkan siswa tidak punya inisiatif sendiri (Uno dan Muhamad, 2012).

Metode pembelajaran yang dapat diterapkan dalam proses pembelajaran untuk dapat mengaktifkan siswa adalah Giving Question and Getting Answer. Menurut Suprijono (2009) "Metode Giving Question and Getting Answer merupakan metode yang dapat melibatkan aktifitas siswa dan memberikan kesempatan pada peserta didik untuk melatih kemampuan dan keterampilan bertanya dan menjawab pertanyaan". Selain mengaktifkan siswa dalam proses pemebelajaran, kegiatan bertanya dan menjawab juga dapat menumbuhkan pengetahuan baru pada siswa. Adapun kelebihan metode Giving Question and Getting Answer adalah suasana pembelajaran lebih aktif, siswa mendapat kesempatan menanyakan hal-hal yang belum dimengerti, guru dapat mengetahui kemampuan siswa dalam menguasai materi yang telah disampaikan, mendorong siswa untuk berani mengajukan pendapatnya, setiap siswa mempunyai kesempatan yang sama untuk bertanya dan berpendapat. Namun, perlu diperhatikan fokus materi karena melalui bertanya dan menjawab dapat meluas kajian materinya (Prima, 2013: 29-30).

Ekosistem merupakan materi biologi yang cukup padat dengan konsep, hal ini tentu menjadi membosankan bagi siswa apabila diajarkan dengan cara yang konvensional. Untuk itu, melalui Giving Question and Getting Answer pengajaran materi ekosistem dibuat lebih menyenangkan sehingga dapat meningkatkan keaktifan belajar siswa.

Penelitian ini bertujuan untuk mengetahui pengaruh metode Giving Question and Getting Answer terhadap keaktifan belajar siswa pada materi Ekosistem Kelas X di SMA Negeri 1 Krangkeng.

\section{MATERI DAN METODE}

\section{Jenis Dan Metode Penelitian}

Penelitian ini merupakan jenis penelitian kuantitatif. Menurut Sugiyono (2013:14) metode penelitian kuantitatif dapat diartikan sebagai metode penelitian yang berlandaskan pada filsafat positivisme, digunakan untuk meneliti pada populasi atau sampel tertentu, teknik pengambilan sampel pada umumnya dilakukan secara random, pengumpulan data menggunakan instrumen penelitian, analisis data bersifat kuantitatif atau statistik dengan tujuan untuk menguji hipotesis yang telah ditetapkan. Desain penelitian yang digunakan adalah true experimental design, yang memiliki ciri, sampel yang digunakan diambil secara random dari populasi tertentu dan adanya kelas kontrol Sugiyono (2013:112).

Populasi penelitian ini adalah seluruh siswa kelas X SMA Negeri 1 Krangkeng. Teknik pengambilan sampel menggunakan Cluster Random Sampling. Hasil pemilihan sampel menetapkan kelas X MIPA 1 sebagai kelas eksperimen dan X MIPA 2 sebagai kelas kontrol. Variabel bebas pada penelitian ini adalah metode Giving Question and Getting Answer dan variabel terikat adalah keaktifan belajar siswa.

\section{Prosedur Penelitian}

Penelitian ini dilakukan melalui beberapa tahap, diantaranya yaitu:

1. Tahap Persiapan

Dilakukan beberapa kegiatan pada tahap ini sebelum pada akhirnya dilakukan penelitian. Pertama, melakukan studi lapangan, studi pustaka, membuat Rencana Pelaksanaan Pembelajaran (RPP) dengan metode Giving Question and Getting Answer. Membuat instrumen penelitian (lembar observasi) untuk mengukur keaktifan belajar siswa.

2. Tahap Pelaksanaan

Pelaksanaan penelitian dilakukan pada dua kelas, yaitu kelas eksperimen dan kelas kontrol dengan desain pos test only control group. Pada kelas eksperimen pengajaran menggunakan metode Giving Question and Getting Answer dan pada kelas kontrol metode diskusi (yang biasa dilakukan di sekolah). Kedua kelas diberikan materi ekosistem dan dilakukan di SMA Negeri 1 Krangkeng selama dua pertemuan.

3. Tahap pengamatan 
Pengamatan dan pengumpulan data dilakukan selama proses pembelajaran, dengan menggunakan lembar observasi yang berdasarkan pada indikator keaktifan belajar siswa.

\section{Teknik Pengumpulan Data}

Pengumpulan data dalam penelitian ini menggunakan lembar observasi, menurut Sugiyono (2013) "Observasi tersetruktur adalah observasi yang telah dirancang secara sistematis, tentang apa yang akan ditelitih, kapan dan di mana tempatnya".

Dalam observasi ini peneliti melakukan kolaborasi dengan observer, fungsi kolaborasi ini untuk membantu peneliti dalam melakukan pengamatan terhadap keaktifan belajar siswa metode ini bertujuan untuk mengamati secara langsung ke objek penelitian guna memperoleh data tentang kegiatan selama pembelajaran berlangsung. Lembar observasi di lakukan selama proses pembelajaran berlangsung pada kelas eksperimen dan kelas kontrol.

Sebelum lembar observasi ini digunakan, maka dilakukan terlebih dahulu uji coba instrumen yaitu dengan validitas logis yang dinilai oleh beberapa ahli.

\section{Teknik Analisis Data}

Setelah data didapatkan, maka dilakukan analisis inferensial karena data diambil dari sampel untuk menyimpulkan populasi. Jenis statistiknya adalah parametrik. Untuk dapat masuk uji parametrik, maka dilakukan uji prasyarat yaitu: uji normalitas dengan chi quadrat $(\chi 2)$ dan uji homogenitas (uji F). Setelah itu baru dilakukan uji hipotesis dengan uji-tt dua sample satu pihak. Berikut hipotesis penelitiannya:

$$
\begin{array}{ll}
\mathrm{H}_{0}: & \mu_{1} \leq \mu_{2} \\
\mathrm{H}_{\mathrm{a}}: & \mu_{1}>\mu_{2}
\end{array}
$$

Dengan $\mu_{1}$ adalah kelas eksperimen dan $\mu_{2}$ kelas kontrol. Rumus uji-t dua sampel yang digunakan dalam penelitian ini adalah berdasarkan Sudjana (2005:239).

$$
t=\frac{\bar{x}_{1}-\bar{x}_{2}}{\sqrt{S_{g a b}^{2}\left(\frac{1}{n_{1}}+\frac{1}{n_{2}}\right)}}
$$

\section{HASIL}

\section{Hasil Keaktifan Belajar Siswa Pada Kelas Kontrol dan Kelas Eksperimen}

Penelitian dilakukan dengan memberikan perlakuan berupa metode Giving Question and Getting Answer di kelas ekperimen dan menggunakan metode konvensional (seperti biasanya di sekolah) pada kelas kontrol. Setelah dilakukan pengolahan data dari dua kelas, maka didapatkan data seperti pada Tabel.1 berikut:

Tabel.1 Rata-rata Keaktifan Belajar Siswa Menggunakan Metode Giving Question and Getting Answer dan Yang Menggunakan Metode Konvensional

\begin{tabular}{ccc}
\hline Nilai & $\begin{array}{c}\text { Metode Giving } \\
\text { Question And } \\
\text { Getting Answer }\end{array}$ & $\begin{array}{c}\text { Metode } \\
\text { Konvensional }\end{array}$ \\
\hline Jumah & 30 & 29 \\
Siswa & & \\
Skor Maks & 36 & 34 \\
Skor Min & 26 & 24 \\
Sekor ideal & 40 & 40 \\
Rata-rata & 31,97 & 29,40 \\
Simpangan & 2,34 & 2,04 \\
baku & & \\
\hline
\end{tabular}

Berdasarkan Tabel.1 skor tertinggi keaktifan belajar siswa pada kelas yang menggunakan metode Giving Question And Getting Answer yang dicapai siswa yaitu 36 dan skor ter rendah yaitu 26, dan nilai rata-rata keaktifan belajar siswa dalam pembelajaran menggunakan metode Giving Question And Getting Answer memperoleh skor 31,97 dengan simpangan baku 2,34 . Sedangkan pada kelas yang menggunakan metode konvensional yang dicapai siswa yaitu 34 dan skor terendah yaitu 24 , dan nilai rata-rata keaktifan belajar siswa sebanyak 29,40 dengan simpangan baku 2,04. 


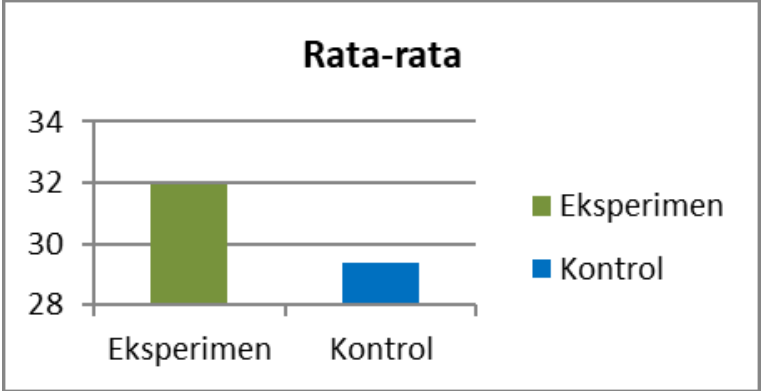

Gambar.1 Rata-rata Keaktifan Belajar Siswa Pada Kelas Kontrol dan Kelas Eksperimen

Pada Gambar.1 dapat dilihat bahwa skor rata-rata keaktifan belajar siswa kelas yang pembelajaranya menggunakan metode Giving Question and Getting Answer $(31,97)$ lebih baik dibandingkan dengan kelas yang pembelajaranya menggunakan metode konvensional $(29,40)$. Namun untuk dapat mengatakan berpengaruh atau tidak, perlu dilakukan uji-t dua sampel.

\section{Keaktifan Belajar Siswa Per Indikator Pada Kelas Kontrol Dan Kelas Eksperimen}

Secara umum, sudah diketahui bahwa kelas eksperimen memiliki rata-rata keaktifan belajar yang lebih baik dari pada kelas kontrol. Dalam hal ini, dijelaskan keaktifan belajar siswa per indikatornya seperti pada Tabel.2

Tabel.2 Rata-rata Skor Per Indikator Keaktifan Belajar Siswa Kelas Kontrol dan Kelas Eksperimen

\begin{tabular}{lcc}
\hline \multicolumn{1}{c}{ Indikator } & $\begin{array}{c}\text { Rata-rata } \\
\text { Kelas } \\
\text { Kontrol }\end{array}$ & $\begin{array}{c}\text { Rata-rata } \\
\text { Kelas } \\
\text { Eksperimen }\end{array}$ \\
\hline Visual activities & 4 & 4.3 \\
Listening & 3,8 & 3.8 \\
activities & & \\
Mental activities & 3,5 & 4.2 \\
Oral activities & 3,3 & 3.7 \\
Writing & 3,7 & 4.0 \\
activities & &
\end{tabular}

Berdasarkan Tabel.2 indikator aktivitas visual pada kedua kelas memiliki skor rata-rata tertinggi dibandingkan dengan indikator lainnya. Sedangkan indikator aktivitas oral memiliki skor rata-rata paling rendah dari kedua kelas. Dan untuk indikator aktivitas mendengarkan pada kelas kontrol dan kelas ekperimen memiliki skor yang sama. Untuk dapat menggambarkan lebih jelas maka dapat dilihat pada Gambar.2

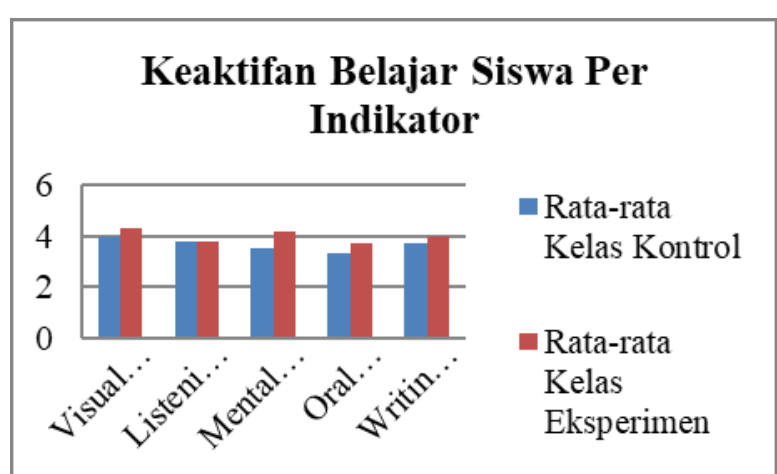

Gambar.2 Rata-rata Keaktifan Belajar Siswa Per Indikator

\section{Hasil Uji Hipotesis}

Sebelum uji hipotesis dilakukan, maka terlebih dahulu uji prasyarat parametrik terlebih dahulu. Demikian akan dipaparkan hasil dari uji prasyarat. Pada Tabel.3 dijelaskan perhitungan dari uji normalitas.

Tabel.3 Hasil Perhitungan Normalitas

\begin{tabular}{lcc}
\multicolumn{1}{c}{ Kelas } & $\chi^{\mathbf{2}_{\text {hitung }}}$ & $\chi^{\mathbf{2}_{\text {tabel }}}$ \\
\hline $\begin{array}{l}\text { Metode Giving } \\
\text { Question And }\end{array}$ & 1.508 & 7.815 \\
$\begin{array}{l}\text { Getting Answer } \\
\text { Metode }\end{array}$ & 1.817 & 7.815 \\
$\begin{array}{l}\text { Pembelajaran } \\
\text { Konvensional }\end{array}$ & & \\
\hline
\end{tabular}

Berdasarkan Tabel.3 maka dapat disimpulkan baik kelas eksperimen maupun kelas kontrol memiliki data yang normal karena $\chi 2_{\text {hitung }}$ lebih kecil dari pada $\chi 2_{\text {tabel }}$.

Untuk menguji homogenitas digunakan uji F, dan hasilnya dipaparkan pada Tabel.4 berikut.

Tabel.4 Hasil Uji Homogenitas

\begin{tabular}{lcccc}
\hline \multicolumn{4}{c}{ Hasil Perhitungan Homogenitas Dua Varians } \\
\hline \multicolumn{1}{c}{ Kelas } & N & Varians & Fhitung & Ftabel \\
\hline Kelas & & & & \\
Eksperimen & 30 & 5,50 & 1,322 & 1,875 \\
Kelas Kontrol & 29 & 4,16 & & \\
\hline
\end{tabular}

Berdasarkan Tabel.4 nilai $\mathrm{F}_{\text {hitung }}$ lebih kecil daripada $\mathrm{F}_{\text {tabel }}$ oleh karena itu dapat disimpulkan bahwa data homogen.

Setelah mengetahui data berdistribusi normal dan homogen, maka selanjutnya dilakukan uji-t dua sampel satu pihak untuk menguji hipotesis penelitian. Berikut hasil dari uji-t dua sampel dijelaskan pada Tabel 5 . 
Tabel.5 Hasil Uji-t dua sampel

\begin{tabular}{lcccc}
\hline \multicolumn{4}{c}{ Hasil Perhitungan Uji Beda Dua Rata-rata } \\
\hline \multicolumn{1}{c}{ Kelas } & $\begin{array}{c}\text { rata- } \\
\text { rata }\end{array}$ & Sgab & $\mathbf{t}_{\text {hitung }}$ & $\mathbf{t}_{\text {tabel }}$ \\
\hline $\begin{array}{l}\text { Kelas } \\
\text { Eksperimen }\end{array}$ & 31,97 & & & \\
$\begin{array}{l}\text { Kelas } \\
\text { Kontrol }\end{array}$ & 29,40 & 4,84 & 4,486 & 1,672 \\
\hline
\end{tabular}

Berdasarkan Tabel.5 dapat dilihat bahwa pembelajaran yang menggunakan metode Giving Question and Getting Answer mendapat rata-rata 31,97 dan yang pembelajaran yang menggunakan metode konvensional mendapat rata-rata 29,40 dengan $t_{\text {hitung }} 4,486$ dengan taraf signifikan $\alpha=0,05$ dan derajat kebebasan $(\mathrm{db})=57$ diperoleh $t_{\text {tabel }}$ 1,672. Dari data tersebut dapat disimpulkan bahwa $t_{\text {hitung }}>t_{\text {tabel }}$, karena $t_{\text {hitung }}>t_{\text {tabel }}$ maka Ho ditolak. Artinya terdapat pengaruh penggunaan metode Giving Question and Getting Answer terhadap keaktifan belajar siswa.

\section{PEMBAHASAN}

\section{Hasil Keaktifan Belajar Siswa Pada Kelas Eksperimen Dan Kelas Kontrol}

Berdasarkan Gambar.1 nilai rata-rata siswa yang menggunakan metode Giving Question and Getting Answer lebih tinggi dari siswa yang menggunakan metode konvensional. Penggunaan metode Giving Question and Getting Answer siswa dituntut untuk bertanya dan mejawab pertanyaan. Melalui kegiatan bertanya, siswa bisa berdiskusi dengan teman mengenai materi yang belum dimengerti atau materi yang belum jelas. Dan dengan kegiatan menjawab pertanyaan, melatih siswa untuk percaya diri dengan pendapatnya dan membuat siswa lebih aktif dalam mencari literatur untuk menjawab pertanyaan. Sehingga dengan kegiatan tanya jawab tersebut suasana kelas selama proses pembelajaran menjadi aktif dan siswa tidak ada yang mengobrol diluar materi. Selain itu, terjadi interaksi antara siswa dengan siswa dan siswa dengan guru, hal itu membuat siswa tidak jenuh selama proses pembelajaran dan siswa mudah memahami materi daur biogeokima. Sesuai dengan pendapat Nuryani yang dikutip oleh Sari (2017) yaitu pertanyaan diajukan siswa untuk memenuhi rasa ingin tahu dan memperjelas halhal yang kurang dipahami.

Berdasarkan Tabel.1 skor rata-rata keaktifan belajar siswa pada kelas yang menggunakan metode konvensional lebih kecil dibandingkan dengan yang menggunakan metode Giving Question and Getting Answer. Hal ini dikarenakan selama proses pembelajaran siswa dan kegiatan diskusi siswa kurang berinteraksi dengan anggota kelompoknya. Dalam kegiatan diskusi hanya siswa tertentu yang aktif dalam diskusi sedangkan anggota lainya hanya mengobrol diluar materi yang dibahas. Pada kegiatan tanya jawab hanya siswa tertentu yang berani bertanya dan menjawab pertanyaan siswa lainya hanya mengikuti apa yang ditanyakan oleh temannya dan menerima jawaban seadanya. Serta kurangnya rasa ingin tahu siswa terhadap materi yang sedang diajarkan sehingga keaktifan belajar siswa rendah. Hal ini sependapat dengan Rosyida (2009:44) bahwa kurang aktifnya siswa selama proses pembelajaran ditandai dengan rendahnya keberanian siswa untuk bertanya dan siswa malas membaca materi.

Dari penjelasan diatas metode Giving Question and Getting Answer memiliki rata-rata skor keaktifan belajar siswa lebih baik dari metode konvensional. Hal ini sesuai dengan penelitian Erdas (2015) dan Juharti (2013) hal ini juga di dukung oleh pendapat Suprijono (2009) bahwa metode Giving Question And Getting Answer merupakan metode yang dapat melibatkan aktifitas siswa.

\section{Hasil Keaktifan Belajar Siswa Per Indikator Pada Kelas Eksperimen Dan Kelas Kontrol}

Berdasarkan Tabel.2 jumlah skor keaktifan belajar siswa pada indikator Visual activities kelas eksperimen rata-ratanya 4,3 dan kelas yang pembelajaranya menggunakan metode konvensonal rata-ratanya 4,0. Hal ini dikarenakan sebagaian besar siswa memperlihatkan adanya minat, memperhatikan ketika guru menyampaikan materi, motivasi kesiapan dalam mengikuti kegiatan pembelajaran, dan kemampuan siswa berpendapat, serta meningkatkan rasa tanggung jawab siswa untuk mempelajari materi dan menyampaikannya kepada orang lain. Sedangkan pada kelas yang pembelajaranya menggunakan metode konvensional siswa cenderung kurang siap ketika pembelajaran dimulai dan ketika guru menyampaikan materi siswa ngobrol dengan teman sebangkunya, hal ini dikarenakan siswa kurang rasa ingin tahu terhadap materi yang 
sedang diajarkan. Hal ini sesuai dengan pendapat Antiyani (2015).

Jumlah skor keaktifan belajar siswa pada indikator Listening Activities kelas eksperimen rata-ratanya 3,8 dan kelas yang pembelajaranya kontrol rata-ratanya 3,8. Meskipun skor rata-rata keaktifan belajar siswa sama tetapi selama proses pembelajaran dikelas siswa yang menggunakan metode metode Giving Question and Getting Answer dengan kelas yang pembelajaran menggunakan metode konvesional berbeda, kelas yang pembelajaranya menggunakan metode Giving Question and Getting Answer siswa ketika teman 1 kelompoknya berpendapat siswa lainya cepat merespon dan langsung mendiskusikan apa yang dibahas sehingga selama diskusi siswa tidak ada yang pasif, sedangkan kelas yang pembelajaranya menggunakan metode konvensional ketika kegiatan diskusi siswa hanya mendengarkan apa yang temannya paparkan tanpa ada yang merespon. Hal tersebut, sependapat dengan Prima (2013).

Pada indikator Mental Activities kelas eksperimen rata-ratanya lebih baik dibandingkan dengan kelas kontrol. Hal ini dikarenakan siswa antusias ketika belajar kelompok. Melalui pembelajaran kelompok, siswa dapat berdiskusi dengan teman kelompoknya mengenai materi yang telah diajarkan. Interaksi yang terjadi pada pembelajaran kelompok terjadi antar siswa, dan ketika diskusi siswa saling mengemukakan pendapatnya, sejalan dengan pendapat Denis (2013) bahwa kegiatan diskusi siswa dapat berbagi informasi atau pengetahuan. Sedangkan pada kelas kontrol, hanya siswa tertentu yang aktif sedangkan siswa lainya cenderung lebih pasif.

Pada indikator Oral Activities kelas eksperimen rata-ratanya 3,7 dan kelas kontrol rata-ratanya 3,3. Hal ini dikarenakan siswa diberikan kesempatan untuk berani bertanya dan siswa juga dilatih untuk berani perpendapat atau menjawab pertanyaan baik dari guru ataupun sesama teman, sehingga proses pembelajaran dikelas jadi lebih aktif. Melalui kegiatan tersebut, siswa dilatih untuk berani dan percaya diri. Hal ini sejalan dengan pendapat Chasanah dkk. (2012), bahwa berani bertanya dan berpendapat dapat membantu siswa meningkatkan kualitas proses pembelajaran. Sedangkan pada kelas yang pembelajaranya menggunakan metode konvensional ketika siswa presentasi hanya siswa tertentu yang berani bertanya dan menjawab pertanyaan siswa lainya hanya mengikuti dan menerima serta kurangnya rasa percaya diri siswa.

Indikator Writing Activities kelas eksperimen rata-rata lebih baik dibandingkan dengan kelas kontrol. Hal ini dikarenkan, saat guru menyampaikan materi dan diskusi serta kegiatan tanya jawab siswa diwajibkan untuk mencatat atau menulis dengan mencatat dan menulis tersebut membantu siswa untuk mengulang apa yang sudah dipelajari sehingga proses pembelajaran menjadi aktif, hal ini sejalan dengan slamet yang dikutip oleh Erdas (2015) bahwa dalam proses belajar mengajar, guru perlu memunculkan aktivitas siswa dalam berpikir dan berbuat. Sedangkan pada kelas kontrol, siswa jarang yang mencatat apa yang guru jelaskan dan hanya berpusat pada buku paket.

Hal ini sejalan dengan penelitian Erdas (2015) dan Juharti (2013), dan diperkuat oleh Ashari dikutip oleh Prima W (2013) bahwa metode Giving Question And Getting Answer, dapat meningkatkan suasana pembelajaran lebih aktif.

\section{Pengaruh Metode Giving Question And Getting Answer Terhadap Keaktifan Belajar Siswa Pada Materi Ekosistem}

Untuk menjawab hipotesis penelitian, maka di lakukan uji-t dua sampel. Sebelum uji hipotesis, data hasil penelitian diuji normalitas terlebih dahulu kemudian di uji homogenitas. Hasil dari kedua uji tersebut didapatkan data berdistribusi normal dan homogen. Karena data hasil observasi keaktifan belajar siswa berdistribusi normal dan homogen maka dilanjutkan dengan uji-t dua sampel. Berdasarkan Tabel.5 dapat dilihat nilai $\mathrm{t}_{\text {hitung }}=4,486$ dan $t_{\text {tabel }}=1,672$, karena $t_{\text {hitung }}>t_{\text {tabel }}$, maka tolak Ho. Artinya terdapat pengaruh metode Giving Question and Getting Answer terhadap keaktifan belajar siswa.

Pembelajaran yang menggunakan metode Giving Question and Getting Answer dapat membuat suasana kelas menjadi aktif, hal ini karena siswa dituntut berani bertanya dan menjawab pertanyaan dengan bantuan potongan potongan kertas. Kegiatan diskusi menggunakan metode Giving Question and Getting Answer berlangsung terarah tidak ada siswa yang mengobrol diluar materi pelajaran, sehingga terjadi interaksi antar anggota kelompok. Dengan mewajibkan bertanya dan mejawab pertanyaan, siswa akan mencari literatur mengenai materi yang dibahas dan membaca ulang materi yang 
sudah dijelaskan oleh guru. Hal ini sejalan dengan pendapat Uno dan Mohamad (2012 :) bahwa, makin banyak keterlibatan indra dalam proses belajar, makin maksimal keaktifan siswa. Pembelajaran yang mengaktifkan siswa antara lain, mendesain pembelajaran yang dapat membuat siswa aktif sepenuhnya dalam proses belajar, membebaskan siswa dari ketergantungan yang berlebihan pada guru (Uno dan Muhamad, 2012).

Dalam kegiatan tanya jawab berguna untuk, mengali informasi, baik administrasi maupun akademis, mengecek pemahaman siswa, membangkitkan respon pada siswa, mengetahui sejauh mana rasa keingintahuan siswa, dan mengetahui hal-hal yang sudah diketahui siswa. Selama proses pembelajaran berlangsung, siswa mendengarkan dan memperhatikan ketika guru menjelaskan materi. Dan ketika diskusi kelompok siswa aktif sehingga siswa siap dan berani ketika akan mengajukan pertanyaan dan menjawab pertanyaan. Hal ini sependapat dengan Erdas (2015) bahwa penerapan metode Giving Question and Getting Answer dapat mengecek kepemahaman siswa sebagai dasar perbaikan proses belajar mengejar. Selain itu, diungkapkan juga pendapat Nuryani yang dikutip oleh Sari (2017:54-55) bahwa dalam proses belajar mengajar pertanyaan diajukan oleh siswa atau guru. Hasil ini, sesuai dengan penelitian Erdas (2015) dan Juharti (2013) bahwa metode Giving Question and Getting Answer dapat meningkatkan keaktifan belajar siswa.

Penggunaan metode konvensional belum membuat siswa aktif dalam proses pembelajaran. Karena pada kelas yang menggunakan metode konvensional kegiatan diskusi kurang terarah dan kurangnya interaksi siswa dengan anggota kelompoknya, sehingga selama kegiatan diskusi siswa lebih banyak diam dan mengobrol dengan teman kelompoknya dan ketika presentasi di depan siswa lebih banyak membaca materi yang ada dibuku paket tanpa mencari literatur dari sumber lainya. Siswa juga jarang yang bertanya kepada teman yang presentasi di depan mengenai materi yang sedang dibahas, sehingga siswa cenderung pasif pada saat proses pembelajaran dan kurangnya rasa ingin tahu siswa terhadap materi yang diajarkan. Hal ini sesuai dengan penelitian Abimanyu yang dikutip oleh Sari (2017:55) bahwa terdapat beberapa faktor yang menyebabkan siswa kurang berani dalam memunculkan kemampuan bertanya, antara lain yaitu, guru lebih berperan dalam pembelajaran, kehidupan keluarga dan masyarakat yang tidak membiasakan siswa untuk bertanya, serta kurangnya rasa percaya diri.

Berdasarkan pemaparan hasil penelitian dan pembahasan di atas, dapat dinyatakan bahwa penggunaan metode Giving Question and Getting Answer berpengaruh terhadap keaktifan belajar siswa pada materi ekosistem kelas X di SMA Negeri 1 Krangkeng.

\section{KESIMPULAN}

Berdasarkan hasil dan pembahasan dalam penelitian ini, dapat disimpulkan bahwa metode Giving Question and Getting Answer berpengaruh terhadap keaktifan belajar siswa pada materi ekosistem kelas X.

\section{DAFTAR PUSTAKA}

Uno, H.B. dan Nurdin M. 2012. Belajar Dengan Pendekatan PAILKEM: Pembelajaran Aktif, Inovatif, Lingkungan, Kreatif, Efektif, Menarik. Bumi Aksara. Jakarta

Sardiman A.M. 2016. Interaksi Dan Motivasi Belajar Mengajar. Rajawali Pers. Jakarta

Sugiyono. 2013. Metode Penelitian Pendidikan: Pendekatan Kuantitaif, Kualitatif, dan R\&D. Alfabet. Bandung

Suprijono, A. 2009. Cooperative Learning. Pustaka Pelajar. Yogyakarta

Antiyani. 2015. Efektifitas Model Kembeajaran kooperatif Tipe Jigsaw Terhadap Keatifan Belajar Siswa Pada Materi Pencemaran Lingkungan Di SMA Nnegri 1 Sliyeg. Indramayu. Universitas wiralodra

Sari, R. 2017. Pengaruh Metode Pembelajaran Question Student Have (QSH) Terhadap Keterampilan Bertanya Siswa Pada Materi Sistem Reproduksi Di MAN 1 Indramayu. Indramayu. Universitas Wiralodra

Ahyani Latifah Nur, dkk. 2016. Pengaruh Metode Belajar Model Demonstrasi Terhadap Keaktifan Belajar Siwa.[online] 30 Desember 2016

Chasanah dkk. 2012. Pengaruh Penerepan Model Pembelajaran Giving Question And Getting Answer Terhadap Hasil Belajar Siswa Kelas X SMA N Banyudono Tahun Ajaran 2011/2012. [online] 7 Juni 2017

Denis Purnama. 2013. Peningkatan Keaktifan dan Hasil Belajar Siswa Kelas XI IPS 2 SMA N Turenpada Pokok Bahasa Turun Dengan Pembelajaran Kooperatif Tipe TGT. [online] 11 Juni 2017 
BIOEDUSCIENCE 2018, Vol. 1, No. 1, pp. 11-18

Erdas Gaus Setyawan. 2015. Penerapan Model Pembelajaran Koperatif Learning Tipe Giving Question And Getting Answer Dalam Meningkatkan Keaktifan Untuk Hasil Belajar Siswa Pada Mata Pelajaran Tik Kelas VII SMP N 1 Bekri Tahun Ajaran 2015/2016. [Online]. 24 Desember 2016

Juharti Sri. 2013. Peningkatan Keaktifan dan Hasil Belajar Ipa Melalui Strategi Pembelajaran Giving Question and Getting Answer Pada Siswa Kelas IV SDN Krandan.

Prima, T. 2013. Keefektifan Strategi Giving Question And Getting Answer Terhadap Hasil Belajar Sumber Daya Alam Siswa Kelas IV Sekolah Dasar Negri 06 Petarukan Pemalang. 30 Desember 2016 